\title{
The effectiveness and safety of LMWH for preventing thrombosis in patients with spinal cord injury: a meta-analysis
}

Ze Lin ${ }^{1 \dagger}$, Yun Sun ${ }^{1 \dagger}$, Hang Xue ${ }^{1}$, Lang Chen ${ }^{1}$, Chenchen Yan ${ }^{1}$, Adriana C. Panayi ${ }^{2}$, Bobin Mi ${ }^{* *}$ and Guohui Liu ${ }^{1 *}$ (D)

\begin{abstract}
Background: Unfractionated heparin (UFH) and low molecular weight heparin (LMWH) are commonly used for preventing venous thrombosis of the lower extremity in patients with traumatic spinal cord injury. Although, LMWH is the most commonly used drug, it has yet to be established whether it is more effective and safer than UFH. Further, a comparison of the effectiveness of LMWH in preventing thrombosis at different locations and different degrees of spinal cord injury has also not been clearly defined.
\end{abstract}

Materials and methods: Cohort studies comparing the use of LMWH and UFH in the prevention of lower limb venous thrombosis in patients with spinal cord injury were identified using PubMed. The risk of bias and clinical relevance of the included studies were assessed using forest plots. The Newcastle-Ottawa quality assessment scale was used to evaluate the quality of the included studies. The main results of the study were analyzed using Review Manager 5.3.

Results: A total of five studies were included in this meta-analysis. Four studies compared the effectiveness and safety of LMWH and UFH in preventing thrombosis in patients with spinal cord injury. No significant differences were found between the therapeutic effects of the two drugs, and the summary RR was $1.33(95 \% \mathrm{Cl} 0.42-4.16 ; P=$ 0.63). There was also no significant difference in the risk of bleeding between the two medications, and the aggregate RR was 0.78 (95\% Cl 0.55-1.12; $P=0.18$ ). When comparing the efficacy of LMWH in preventing thrombosis in different segments and different degrees of spinal cord injury, no significant differences were found.

Conclusions: The results of this analysis show that compared with UFH, LMWH has no obvious advantages in efficacy nor risk prevention, and there is no evident difference in the prevention of thrombosis for patients with injuries at different spinal cord segments.

Keywords: Spinal cord injury, Developing venous thromboembolism, Low molecular weight heparin, Unfractionated heparin

\footnotetext{
* Correspondence: mibobin@hust.edu.cn; liuguohui@hust.edu.cn

†Ze Lin and Yun Sun contributed equally to this work.

'Department of Orthopaedics, Union Hospital, Tongji Medical College,

Huazhong University of Science and Technology, Jiefang Road. 1277\#,

Wuhan 430022, Hubei, P. R. China

Full list of author information is available at the end of the article
}

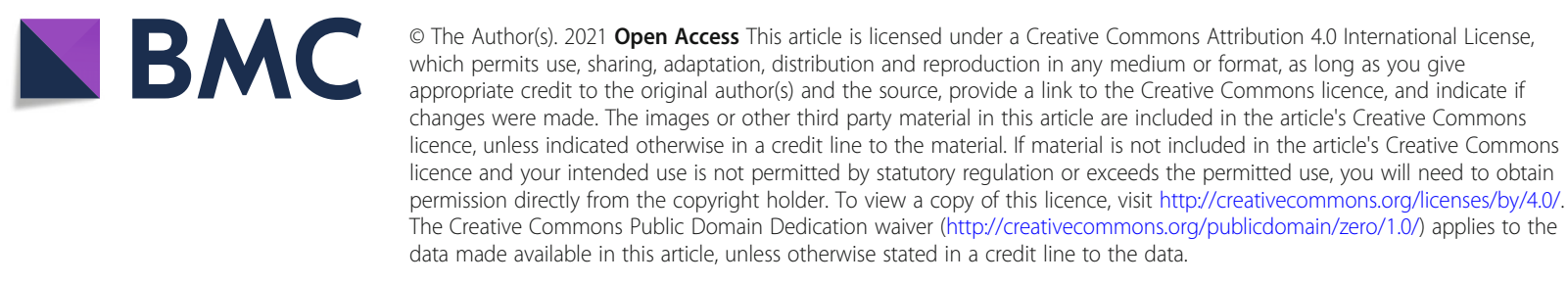




\section{Introduction}

Spinal cord injury (SCI) is common in trauma patients, occurring in more than 41,000 of 900,000 trauma patients each year in the USA [1]. Due to the long recovery time of SCI and the need for long-term bed rest, these patients have a high risk of developing venous thromboembolism (VTE), where VTE includes deep vein thrombosis (DVT) and pulmonary thrombosis (PE) [2-4]. VTE results in a painful recovery, affecting the patient's quality of life, as well as increasing mortality [5-7]. PE is one of the main causes of death in patients with SCI [2]. The American College of Chest Physicians (ACCP) recommends the use of low-dose unfractionated heparin (UFH) or low molecular weight heparin (LMWH) for prevention of thrombus formation in patients with SCI [8]. Compared with UFH, LMWH has the advantages of small molecular weight and long half-life [9-12]. However, the use of LMWH, and whether it has any obvious advantages in the prevention of thrombosis in patients with SCI, remains controversial.

Therefore, the current study aims to determine whether LMWH is more effective in preventing venous thromboembolism in patients with spinal cord injury than unfractionated heparin and to determine whether it has the same efficacy in patients irrespective of the different types or degrees of SCI. This study aims to compare (1) the incidence of inferior venous thrombosis with LMWH treatment or UFH treatment, (2) concurrent bleeding with LMWH treatment or unfractionated heparin treatment, (3) the effect of LMWH treatment on different segments of spinal cord injury, and (4) the effect of LMWH in preventing thrombosis for the treatment of different degrees of spinal cord injury.

\section{Materials and methods \\ Publication search}

This study was conducted according to the guidelines outlined in the PRISMA (Preferred Reporting Items for Systematic Review and Meta-Analysis). The PRISMA checklist can be found in an Additional file, and the PRISMA flow diagram is shown in Fig. 1. The PubMed database was searched for cohort studies published between January 1980 and October 2020. In the search process, we used medical subject terms (MeSH) and combined the following free words: "Spinal Cord

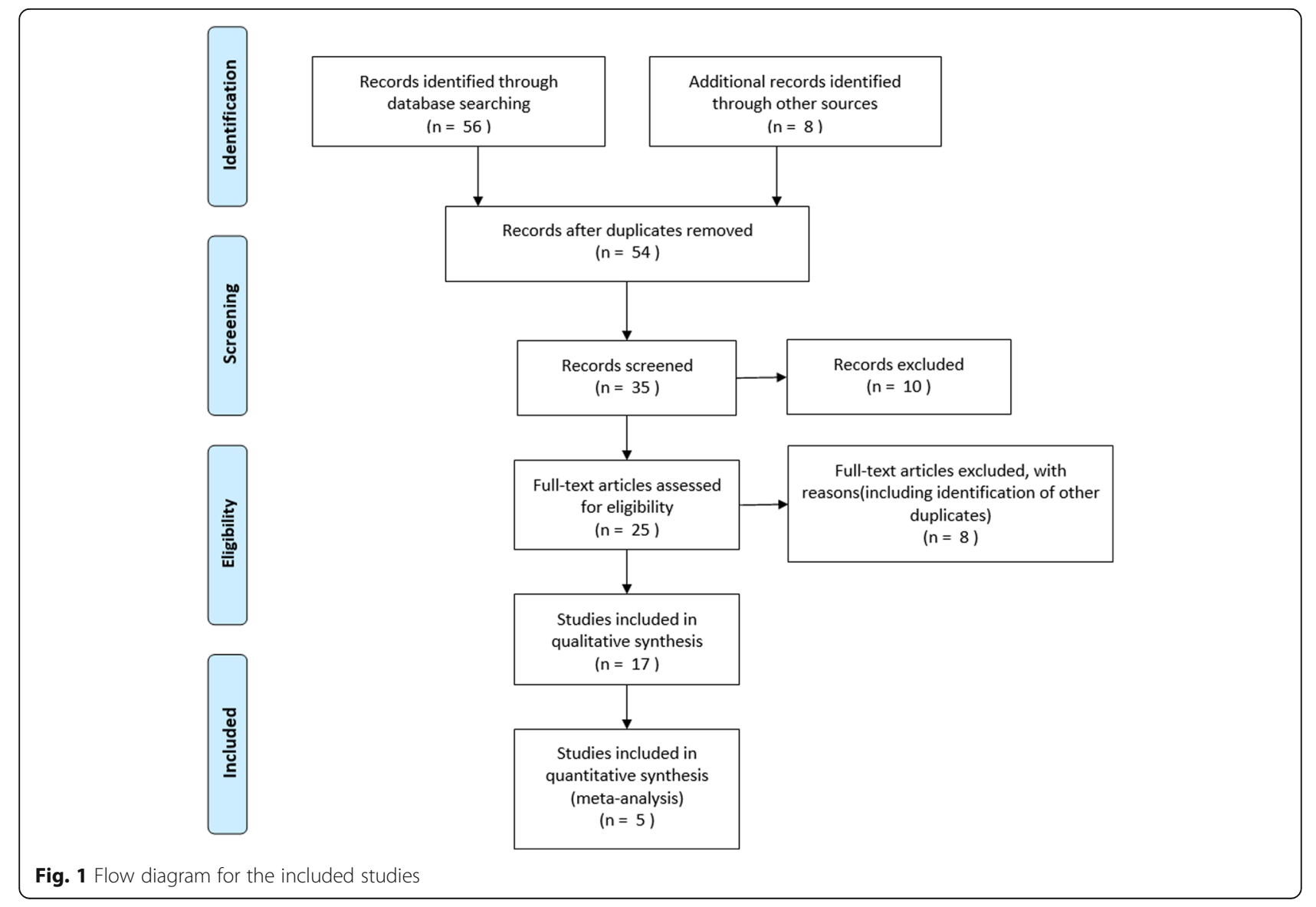


Table 1 Newcastle-Ottawa quality assessment scale of included studies

\begin{tabular}{|c|c|c|c|c|c|c|c|c|}
\hline \multirow[t]{2}{*}{ Author (year) } & \multicolumn{4}{|l|}{ Selection } & \multirow{2}{*}{$\begin{array}{l}\text { Comparability } \\
\text { Comparability } \\
\text { of cohorts on } \\
\text { the basis of } \\
\text { the design } \\
\text { or analysis }\end{array}$} & \multicolumn{3}{|l|}{ Outcome } \\
\hline & $\begin{array}{l}\text { Representativeness } \\
\text { of the exposed } \\
\text { cohort }\end{array}$ & $\begin{array}{l}\text { Selection } \\
\text { of the } \\
\text { non-exposed } \\
\text { cohort }\end{array}$ & $\begin{array}{l}\text { Ascertainment } \\
\text { of exposure }\end{array}$ & $\begin{array}{l}\text { Demonstration } \\
\text { that outcome of } \\
\text { interest was not } \\
\text { present at start } \\
\text { of study }\end{array}$ & & $\begin{array}{l}\text { Assessment } \\
\text { of outcome }\end{array}$ & $\begin{array}{l}\text { Was follow-up } \\
\text { long enough } \\
\text { for outcomes } \\
\text { to occur }\end{array}$ & $\begin{array}{l}\text { Adequacy of } \\
\text { follow-up of } \\
\text { cohorts }\end{array}$ \\
\hline $\begin{array}{l}\text { Ahlquist et al. } \\
\text { (2020) [16] }\end{array}$ & 1 & 1 & 1 & 0 & 0 & 1 & 1 & 0 \\
\hline $\begin{array}{l}\text { Hamidi et al. } \\
\text { (2019) [17] }\end{array}$ & 1 & 1 & 1 & 0 & 1 & 1 & 0 & 0 \\
\hline $\begin{array}{l}\text { Worley et al. } \\
\text { (2008) [18] }\end{array}$ & 1 & 1 & 1 & 0 & 1 & 1 & 0 & 0 \\
\hline $\begin{array}{l}\text { Spinal Cord Injury } \\
\text { Thromboprophylaxis } \\
\text { Investigators. } \\
\text { (2003) [19] }\end{array}$ & 1 & 1 & 1 & 1 & 1 & 1 & 0 & 0 \\
\hline $\begin{array}{l}\text { Thumbikat et al. } \\
\text { (2002) [20] }\end{array}$ & 1 & 1 & 1 & 1 & 1 & 1 & 0 & 0 \\
\hline
\end{tabular}

Injuries," "Spinal Cord Trauma," "Spinal Cord Laceration," "Spinal Cord Contusion," "Heparin," "Heparin, Low Molecular Weight," "LMWH," "Venous Thromboembolism" and "Thromboembolism, Venous."

\section{Inclusion criteria}

The inclusion criteria were as follows: (1) The study was designed as a clinical cohort study; (2) the study included SCI patients treated with LMWH or UFH; (3) the main outcome measured was VTE formation as indicated by ultrasound or CT; (4) the article was written in English or had been translated into English.

\section{Data extraction and quality assessment}

Two authors extracted the following information from the selected literature: first author, date of publication, characteristics of the research object, therapeutic drugs used, spinal cord injury, study design. The quality of the cohort studies was evaluated using the Newcastle-Ottawa Scale (NOS) by two authors independently [13-15]. Discussion with a third reviewer resolved any differences (Table 1).

\section{Statistical analysis}

Statistical analysis was performed using Review Manager (version 5.3, Copenhagen: Nordic Cochrane Centre, Cochrane Collaboration, 2014). All results are presented

Table 2 The characteristics of included studies

\begin{tabular}{|c|c|c|c|c|c|c|c|c|c|c|c|}
\hline \multirow[t]{2}{*}{ Study/year } & \multirow[t]{2}{*}{ Patients } & \multirow{2}{*}{$\begin{array}{l}\text { Gender } \\
\text { (male,\%) }\end{array}$} & \multirow[t]{2}{*}{ Interventions } & \multicolumn{3}{|c|}{ Cord injury level } & \multirow[t]{2}{*}{ Tetraplegia } & \multirow[t]{2}{*}{ Paraplegia } & \multicolumn{2}{|l|}{ AIS } & \multirow{2}{*}{$\begin{array}{l}\text { Study } \\
\text { design }\end{array}$} \\
\hline & & & & Cervical & Thoracic & Lumber & & & $\begin{array}{l}\text { A/ } \\
\text { B }\end{array}$ & $\begin{array}{l}\mathrm{Cl} \\
\mathrm{D} / \\
\mathrm{E}\end{array}$ & \\
\hline $\begin{array}{l}\text { Ahlquist et al. } \\
2020 \text { [16] }\end{array}$ & 79 & 61.0 & $\begin{array}{l}\text { LMWH } \\
\text { (40 mg daily)/UFH } \\
\text { (5000 U twice daily) }\end{array}$ & 49 & 28 & 2 & - & - & 44 & 46 & $\begin{array}{l}\text { Retrospective } \\
\text { cohort study }\end{array}$ \\
\hline \multirow{2}{*}{$\begin{array}{l}\text { Hamidi et al. } \\
2019 \text { [17] }\end{array}$} & \multirow[t]{2}{*}{810} & \multirow[t]{2}{*}{58.0} & LMWH & 98 & 189 & 175 & \multirow[t]{2}{*}{-} & \multirow[t]{2}{*}{-} & \multirow[t]{2}{*}{-} & \multirow[t]{2}{*}{-} & \multirow{2}{*}{$\begin{array}{l}\text { Retrospective } \\
\text { cohort study }\end{array}$} \\
\hline & & & DOACs & 57 & 74 & 95 & & & & & \\
\hline \multirow[t]{2}{*}{$\begin{array}{l}\text { Worley et al. } \\
2008 \text { [18] }\end{array}$} & \multirow[t]{2}{*}{79} & \multirow[t]{2}{*}{49.0} & $\begin{array}{l}\text { LDUH (heparin } \\
5000 \text { U twice daily) }\end{array}$ & \multirow[t]{2}{*}{ - } & \multirow[t]{2}{*}{ - } & \multirow[t]{2}{*}{ - } & 35 & 12 & 24 & 23 & \multirow[t]{2}{*}{$\begin{array}{l}\text { Retrospective } \\
\text { cohort study }\end{array}$} \\
\hline & & & $\begin{array}{l}\text { LMWH (dalteparin } \\
5000 \text { units daily) }\end{array}$ & & & & 25 & 18 & 20 & 23 & \\
\hline \multirow{2}{*}{$\begin{array}{l}\text { Spinal Cord Injury } \\
\text { Thromboprophylaxis } \\
\text { Investigators } 2003 \text { [19] }\end{array}$} & \multirow[t]{2}{*}{476} & \multirow[t]{2}{*}{81.7} & $\begin{array}{l}\text { UFH } \\
\text { (5000 U every } 8 \mathrm{~h})\end{array}$ & \multirow[t]{2}{*}{-} & \multirow[t]{2}{*}{-} & \multirow[t]{2}{*}{-} & 147 & 73 & 215 & 31 & \multirow[t]{2}{*}{$\begin{array}{l}\text { Retrospective } \\
\text { cohort study }\end{array}$} \\
\hline & & & $\begin{array}{l}\text { Enoxaparin } \\
\text { (30 mg every } 12 \text { h) }\end{array}$ & & & & 130 & 67 & 191 & 39 & \\
\hline \multirow[t]{2}{*}{$\begin{array}{l}\text { Thumbikat et al. } \\
2002[20]\end{array}$} & \multirow[t]{2}{*}{173} & \multirow[t]{2}{*}{74.6} & $\begin{array}{l}\text { Heparin } \\
\text { ( } 5000 \text { U twice daily) }\end{array}$ & 36 & 46 & 19 & \multirow[t]{2}{*}{-} & \multirow[t]{2}{*}{-} & \multirow[t]{2}{*}{ - } & \multirow[t]{2}{*}{-} & $\begin{array}{l}\text { Retrospective } \\
\text { cohort study }\end{array}$ \\
\hline & & & $\begin{array}{l}\text { Enoxaparin } \\
\text { (40mg daily) }\end{array}$ & 38 & 24 & 10 & & & & & \\
\hline
\end{tabular}




\begin{tabular}{|c|c|c|c|c|c|c|c|c|c|}
\hline Study or Subgroup & $\begin{array}{l}\text { LMWh } \\
\text { Events }\end{array}$ & Total & $\begin{array}{l}\text { UFH } \\
\text { Events }\end{array}$ & Total & Weight & $\begin{array}{l}\text { Risk Ratio } \\
\text { M-H. Random, } 95 \% \mathrm{Cl}\end{array}$ & $\begin{aligned} \text { Risk } \\
\text { M-H. Rand }\end{aligned}$ & $\begin{array}{l}\text { Ratio } \\
\text { lom. } 95 \% \mathrm{Cl}\end{array}$ & \\
\hline Geerts 2003 & 31 & 58 & 38 & 49 & $33.8 \%$ & $0.69[0.52,0.92]$ & $=$ & & \\
\hline Scott 2008 & 4 & 39 & 3 & 40 & $22.4 \%$ & $1.37[0.33,5.72]$ & & & \\
\hline Seth 2020 & 1 & 9 & 11 & 70 & $17.4 \%$ & $0.71[0.10,4.85]$ & & & \\
\hline Thumbikat 2002 & 13 & 72 & 4 & 101 & $26.4 \%$ & $4.56[1.55,13.41]$ & & - & \\
\hline Total $(95 \% \mathrm{Cl})$ & & 178 & & 260 & $100.0 \%$ & $1.33[0.42,4.16]$ & & & \\
\hline Total events & 49 & & 56 & & & & & & \\
\hline \multicolumn{7}{|c|}{$\begin{array}{l}\text { Heterogeneity: } \mathrm{Tau}^{2}=0.98 ; \mathrm{Ch}^{2}=14.23, \mathrm{df}=3(\mathrm{P}=0.003) ; I^{2}=79 \% \\
\text { Test for overall effect: } Z=0.49(P=0.63)\end{array}$} & $\begin{array}{l}0.002 \\
\quad \text { Favou }\end{array}$ & $\begin{array}{l}10 \\
\text { Favours [c }\end{array}$ & $\frac{1}{500}$ \\
\hline
\end{tabular}

as forest plots. For each effect size, a 95\% confidence interval was determined. Heterogeneity was statistically tested by $I^{2}[21]$.

\section{Result}

\section{Study characteristics}

A total of 64 articles were identified as potentially eligible during the literature search. Duplicate research was eliminated, leaving 54 articles. Thorough review of the details of each study resulted in a preliminary screening of 35 studies. Comprehensive evaluation of the 17 selected manuscripts was conducted. Finally, five articles were found to meet the inclusion criteria of this metaanalysis [16-20]. The details of the included cohort studies are shown in Table 2.

\section{Comparison of efficacy and safety of LMWH and UFH}

Four studies compared the effects of LMWH and UFH in preventing VTE in patients with SCI [16, 18-20]. The incidence of VTE in the LMWH treatment group was 10.3-53.4\%, and the incidence of VTE in the UFH treatment group was $4.0-77.6 \%$. There was significant statistical heterogeneity among the four studies $\left(P=0.003, I^{2}=\right.$ $79 \%$ ). The summary RR was 1.33 (95\% CI $0.42-4.16 ; P=$ 0.63; Fig. 2). These four studies also compared the risk of bleeding in patients with SCI. The heterogeneity among the four studies was not statistically significant
$\left(P=0.023, I^{2}=31 \%\right)$. The summary $\mathrm{RR}$ was 0.78 (95\% CI 0.55-1.12; $P=0.18$ ) (Fig. 3 ).

\section{The effect of LMWH on different segments of spinal cord injury}

Two of the five studies were selected to evaluate the effect of LMWH on preventing VTE formation in different segments of spinal cord injury $[17,20]$. In these two studies, patients with spinal cord injury were divided into cervical spinal cord, thoracic spinal cord, and lumbar spinal cord injury. From the forest diagram, we can conclude that the RR value when comparing cervical spinal cord injury to thoracic spinal cord injury is 0.84 (95\% CI $0.46-1.54 ; P=0.58$; Fig. 4), when comparing cervical spinal cord injury to lumbar spinal cord injury the RR value was 1.05 (95\% CI 0.51-2.14; $P=0.90$; Fig. 5), and when comparing thoracic spinal cord injury to lumbar spinal cord injury the RR value was 1.21 (95\% CI $0.68-$ 2.16; $P=0.51$ ) (Fig. 6). The other two studies compared the outcomes in patients with total paralysis and patients with hemiplegia $[18,19]$, and the RR value was 0.51 (95\% CI $0.12-2.12 ; P=0.35$ ) (Fig. 7).

\section{The effect of LMWH on different degrees of spinal cord injury}

The American Spinal Injury Association Impairment Scale (AIS) is used to assess spinal cord injury [22]. Two

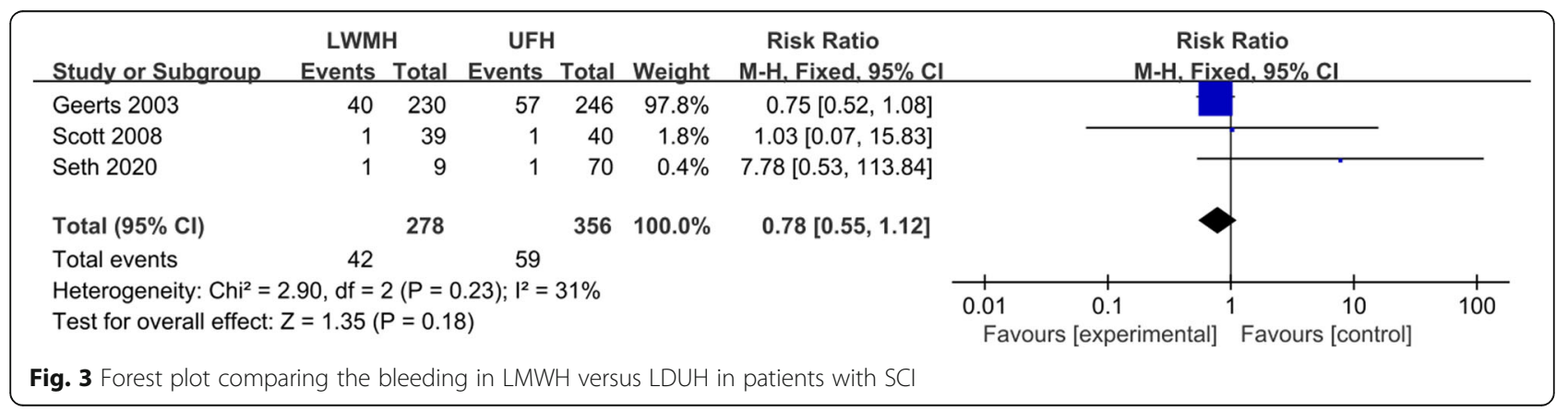




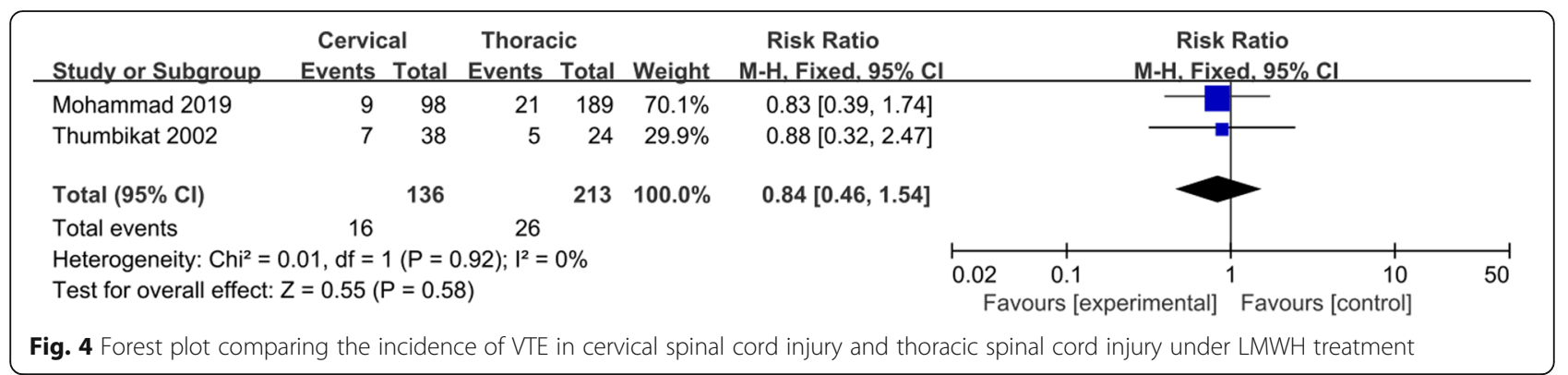

of the five studies used AIS scores to assess patients' spinal cord injury $[16,18]$. The A/B level indicates that the spinal cord injury is more serious, and the $C / D / E$ level indicates that the spinal cord injury is relatively mild. It can be seen from the forest diagram that when the two spinal cord injuries were compared, the RR value is 1 (95\% CI $0.44-2.29 ; P=1.00$; Fig. 8 ).

\section{Discussion}

This meta-analysis was conducted to evaluate the efficacy and safety of LMWH for thromboprophylaxis in spinal cord injury patients and to analyze the effect of LMWH on the prevention of VTE in different sites and at different levels of spinal cord injury.

Our meta-analysis showed that LMWH was not more effective than UFH in preventing VTE $\left(\mathrm{RR}=1.33, I^{2}=\right.$ $79 \%$ ), and there was no significant difference in the incidence of bleeding as a major complication of anticoagulant drugs $\left(\mathrm{RR}=0.78, I^{2}=31 \%\right)$. Prior studies on the prevention and treatment of thrombosis in patients with SCI agree with our study lending support to our conclusions [23]. However, due to the small number of studies that could be included in the meta-analysis, some components of the analyses had significant heterogeneity. Therefore, it cannot be concluded with confidence whether LMWH is superior to UFH in preventing VTE in patients with spinal cord injury, and further research is required.
Compared to existing studies, our analysis is more indepth, assessing the effects of LMWH on the prevention of thrombosis in different spinal cord injury segments and at different degrees of spinal cord injury. The four studies included in our meta-analysis classified patients with spinal cord injury treated with LMWH into different groups according to injury at different segments of the spinal cord [17-20]. However, classification methods for the injured segments differed between studies. Some studies divided injury into that of the cervical spinal cord, thoracic spinal cord, and lumbar spinal cord, while other studies divided injury into total paralysis or hemiplegia. Therefore, we analyzed according to different classification methods, and the results showed that LMWH efficacy in the prevention of thrombosis did not differ between segments.

AIS (the American Spinal Injury Association Impairment Scale) is a scoring scale for evaluating spinal cord injury $[24,25]$. Grade A signifies no motor or sensory function present in the sacral segments S4-S5; grade B means sensory, but not motor, function is preserved below the neurological level and includes the sacral segments $\mathrm{S} 4-\mathrm{S} 5$; grade $\mathrm{C}$ means motor function is preserved below the neurological level, and more than half of key muscles below the neurological level have a muscle grade less than 3; grade $\mathrm{D}$ means motor function is preserved below the neurological level, and at least half of key muscles below the neurological level have a muscle grade of 3 or more; and grade $\mathrm{E}$ means motor

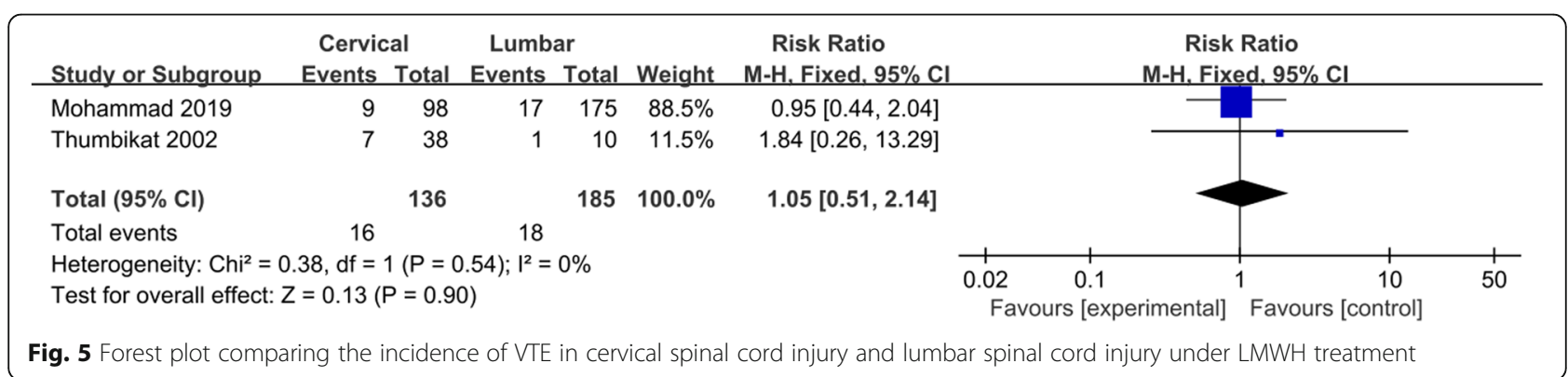




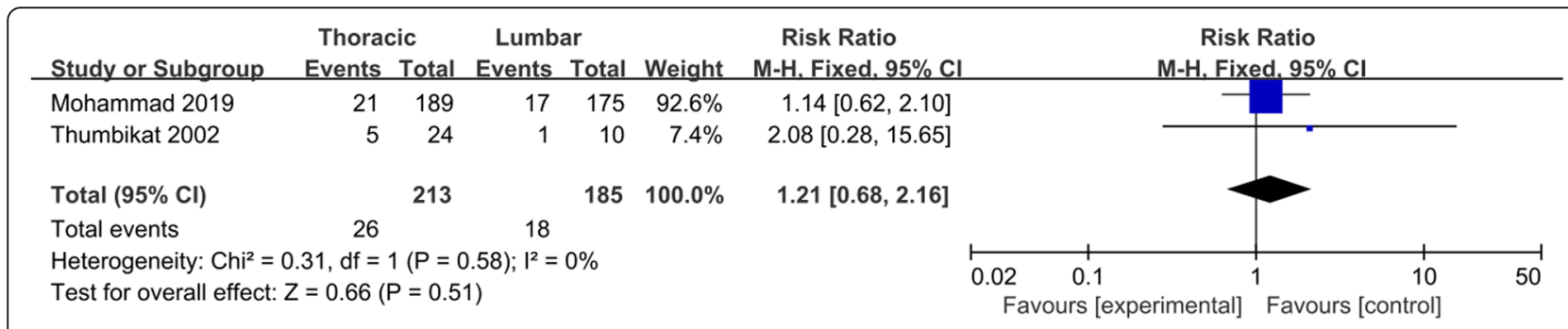

Fig. 6 Forest plot comparing the incidence of VTE in thoracic spinal cord injury and lumbar spinal cord injury under LMWH treatment

and sensory function are normal [22]. The two studies included in this analysis classified patients using the AIS. Therefore, we divided the patients into two groups, those with AIS $\mathrm{A} / \mathrm{B}$ and those with AIS $\mathrm{C} / \mathrm{D} / \mathrm{E}$, in order to evaluate the effect of different degrees of spinal cord injury on the prevention of VTE formation by LMWH. The results showed that there was no significant difference in the incidence of VTE between the two groups of patients.

This meta-analysis is not without limitations. First, only a few studies were identified. For example, only two studies in our analysis discussed the level and degree of injury. A higher number of studies would lend greater credibility to our results, and we expect further research on the subject in the future. When comparing the preventive effects of LMWH and UFH, a significant difference $\left(I^{2}=79 \%\right)$ was noted, decreasing the reliability of the results. However, because the original data in the literature is not conducive to subgroup analysis, we anticipate that future studies will compare the effects of two different anticoagulant drugs in preventing thrombosis in situation with different variables, such as age and degree of spinal cord injury.

In the comparison of efficacy and safety of LMWH and UFH, 4 studies were involved. It is not difficult to find that there are differences in the dosage of the drugs in various studies. However, Miano et al. found that dalteparin (5000 units once a day) and enoxaparin (30 mg twice a day) have similar effects in the efficacy of thrombosis prevention in trauma patients [26]. At the same time, a study reported that the incidence of deep vein thrombosis in patients who received $30 \mathrm{mg}$ of enoxaparin every $12 \mathrm{~h}$ was not significantly different from that of patients who received $40 \mathrm{mg}$ of enoxaparin every day [27]. Therefore, although the four studies included in this metaanalysis contained several different dosages, they were still comparable in their effectiveness in preventing thrombosis.

None of the five studies included in this meta-analysis specifically mentioned the duration of medication. The duration of anticoagulant therapy varies from person to person. During the course of treatment, clinicians will comprehensively evaluate the time of using anticoagulants according to the patient's general physical condition, blood coagulation, and physical rehabilitation training. We believe that the patient received appropriate anticoagulation therapy before the thrombosis assessment, so the impact on the results of this analysis is limited.

It is worth noting that the study by Spinal Cord Injury Thromboprophylaxis Investigators was for SCI patients from 1995 to 1998 [19]. The final statistical results showed a higher thrombosis rate. The reason may be that the surgical methods and postoperative care treatment methods at that time were simpler than the current therapy.

\begin{tabular}{|c|c|c|c|c|c|c|c|c|c|}
\hline Study or Subgroup & $\begin{array}{l}\text { Tetraple } \\
\text { Events }\end{array}$ & $\begin{array}{l}\text { gia } \\
\text { Total }\end{array}$ & $\begin{array}{l}\text { Parapleg } \\
\text { Events }\end{array}$ & $\begin{array}{l}\text { gia } \\
\text { Total }\end{array}$ & Weight & $\begin{array}{l}\text { Risk Ratio } \\
\text { M-H, Random, } 95 \% \text { Cl }\end{array}$ & $\begin{array}{r}\text { Risk R } \\
\text { M-H, Rando } \\
\end{array}$ & $\begin{array}{l}\text { Ratio } \\
\text { om. } 95 \% \mathrm{Cl}\end{array}$ & \\
\hline Geerts 2003 & 31 & 130 & 18 & 67 & $63.0 \%$ & $0.89[0.54,1.46]$ & & & \\
\hline Scott 2008 & 2 & 60 & 5 & 30 & $37.0 \%$ & $0.20[0.04,0.97]$ & & & \\
\hline Total $(95 \% \mathrm{Cl})$ & & 190 & & 97 & $100.0 \%$ & $0.51[0.12,2.12]$ & & & \\
\hline Total events & 33 & & 23 & & & & & & \\
\hline \multicolumn{7}{|c|}{$\begin{array}{l}\text { Heterogeneity: } \mathrm{Tau}^{2}=0.77 ; \mathrm{Chi}^{2}=3.15, \mathrm{df}=1(P=0.08) ; \mathrm{I}^{2}=68 \% \\
\text { Test for overall effect: } Z=0.93(P=0.35)\end{array}$} & $\begin{array}{lll}0.02 & 0.1 & 1 \\
\text { Favours [experimental] }\end{array}$ & Favours [control] & 50 \\
\hline
\end{tabular}




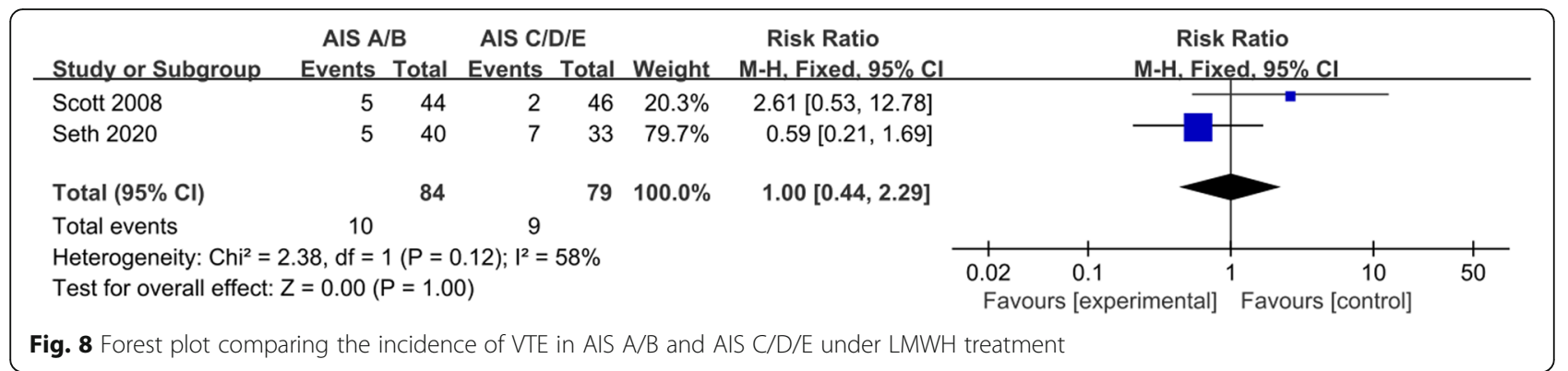

\section{Conclusions}

The results of this analysis show that, compared to UFH, LMWH has no obvious advantages in terms of its preventive effect or risk, and there is no evident difference in the prevention of thrombosis in patients with injuries in different locations of the spinal cord.

\section{Abbreviations}

UFH: Unfractionated heparin; LMWH: Low molecular weight heparin; SCI: Spinal cord injury; VTE: Venous thromboembolism; DVT: Deep vein thrombosis; ACCP: The American College of Chest Physicians; AIS: The American Spinal Injury Association Impairment Scale

\section{Supplementary Information}

The online version contains supplementary material available at https://doi. org/10.1186/s13018-021-02412-7

Additional file 1. The PRISMA Checklist.

\section{Acknowledgements}

Not applicable.

\section{Authors' contributions}

ZL and YS designed, coordinated, and collected the data for the review. HX assisted with the data extraction and analysis. LC assisted with the study selection and quality assessment. CY was involved as the third reviewer to solve disagreement when necessary. AP provided general advice and assisted with the writing of the review. All authors read and approved the final manuscript.

\section{Funding}

This study was funded by the National Major R\&D Program of China and supported by the Department of Orthopedics, Union Hospital, Tongji Medical College, Huazhong University of Science and Technology.

\section{Availability of data and materials}

If the original data is reasonably required, the permission to obtain can be applied to Professor Guohui Liu.

\section{Declarations}

Ethics approval and consent to participate

Not applicable. All analyses were based on previous published studies. This article does not contain any studies with human participants or animals performed by any of the authors.

\section{Consent for publication}

Not applicable.

\section{Competing interests}

The authors declare that they have no competing interests.

\section{Author details}

${ }^{1}$ Department of Orthopaedics, Union Hospital, Tongji Medical College, Huazhong University of Science and Technology, Jiefang Road. 1277\#, Wuhan 430022, Hubei, P. R. China. ${ }^{2}$ The Division of Plastic Surgery, Brigham and Women's Hospital, Harvard Medical School, Boston, MA, USA.

Received: 12 January 2021 Accepted: 6 April 2021

Published online: 14 April 2021

\section{References}

1. Spinal Cord Injury Facts and Figures at a Glance. University of Alabama, Birmingham, Alabama: National Spinal Cord Injury Statistical Center; 2010.

2. Samuel AM, Diaz-Collado PJ, Gala RJ, Webb ML, Lukasiewicz AM, Basques BA, et al. Thromboembolic events after traumatic vertebral fractures: an analysis of 190,192 patients. Spine. 2018;43(18):1289-95. https://doi.org/10.1 097/BRS.0000000000002634

3. Anderson FA, Spencer FA. Risk factors for venous thromboembolism. Circulation. 2003;107(23 Suppl 1):19-16. https://doi.org/10.1161/01.CIR. 0000078469.07362.E6.

4. Eichinger $\mathrm{S}$, Eischer $\mathrm{L}$, Sinkovec $\mathrm{H}$, Wittgruber $\mathrm{G}$, Traby L, Kammer M, et al. Risk of venous thromboembolism during rehabilitation of patients with spinal cord injury. PLoS One. 2018;13(3):e0193735. https://doi.org/10.1371/ journal.pone.0193735.

5. Zhang Z, Lei J, Shao X, Dong F, Wang J, Wang D, et al. Trends in hospitalization and in-hospital mortality from VTE, 2007 to 2016, in China. Chest. 2019;155(2):342-53. https://doi.org/10.1016/j.chest.2018.10.040.

6. Cohen AT, Agnelli G, Anderson FA, Arcelus JI, Bergqvist D, Brecht JG, et al. Venous thromboembolism (VTE) in Europe. The number of VTE events and associated morbidity and mortality. Thromb Haemost. 2007:98(4):756-64.

7. White $\mathrm{RH}$. The epidemiology of venous thromboembolism. Circulation. 2003;107(23 Suppl 1):I4-8. https://doi.org/10.1161/01.CIR.0000078468.11849. 66.

8. Gould MK, Garcia DA, Wren SM, Karanicolas PJ, Arcelus Jl, Heit JA, et al. Prevention of VTE in nonorthopedic surgical patients: antithrombotic therapy and prevention of thrombosis, 9th ed: American College of Chest Physicians Evidence-Based Clinical Practice Guidelines. Chest. 2012;141(2 Suppl):e227S-77S. https://doi.org/10.1378/chest.11-2297.

9. Xiao Z, Théroux P. Platelet activation with unfractionated heparin at therapeutic concentrations and comparisons with a low-molecular-weight heparin and with a direct thrombin inhibitor. Circulation. 1998;97(3):251-6. https://doi.org/10.1161/01.CIR.97.3.251.

10. McRae SJ, Ginsberg JS. Initial treatment of venous thromboembolism. Circulation. 2004;110(9 Suppl 1):I3-9. https://doi.org/10.1161/01.CIR.000014 0904.52752.0c.

11. Cosmi B, Fredenburgh JC, Rischke J, Hirsh J, Young E, Weitz JI. Effect of nonspecific binding to plasma proteins on the antithrombin activities of unfractionated heparin, low-molecular-weight heparin, and dermatan sulfate. Circulation. 1997;95(1):118-24. https://doi.org/10.1161/01.CIR.95.1.118.

12. Stelfox HT, Brundin-Mather R, Soo A, Parsons Leigh J, Niven DJ, Fiest KM, et al. A multicentre controlled pre-post trial of an implementation science intervention to improve venous thromboembolism prophylaxis in critically ill patients. Intensive Care Med. 2019;45(2):211-22. https://doi.org/10.1007/ s00134-019-05532-1.

13. Lo CK-L, Mertz D, Loeb M. Newcastle-Ottawa Scale: comparing reviewers' to authors' assessments. BMC Med Res Methodol. 2014;14(1):45. https://doi. org/10.1186/1471-2288-14-45. 
14. Stang A. Critical evaluation of the Newcastle-Ottawa scale for the assessment of the quality of nonrandomized studies in meta-analyses. Eur J Epidemiol. 2010;25(9):603-5. https://doi.org/10.1007/s10654-010-9491-z.

15. Stang A, Jonas $\mathrm{S}$, Poole C. Case study in major quotation errors: a critical commentary on the Newcastle-Ottawa scale. Eur J Epidemiol. 2018;33(11): 1025-31. https://doi.org/10.1007/s10654-018-0443-3.

16. Ahlquist S, Park HY, Kelley B, Holly L, Shamie AN, Park DY. Venous thromboembolism chemoprophylaxis within 24 hours of surgery for spinal cord injury: is it safe and effective? Neurospine. 2020;17(2):407-16. https:// doi.org/10.14245/ns.1938420.210.

17. Hamidi M, Zeeshan M, Kulvatunyou N, Mitra HS, Hanna K, Tang A, et al. Operative spinal trauma: thromboprophylaxis with low molecular weight heparin or a direct oral anticoagulant. J Thromb Haemost. Jun 2019;17(6): 925-33. https://doi.org/10.1111/jth.14439.

18. Worley S, Short C, Pike J, Anderson D, Douglas J-A, Thompson K. Dalteparin vs low-dose unfractionated heparin for prophylaxis against clinically evident venous thromboembolism in acute traumatic spinal cord injury: a retrospective cohort study. J Spinal Cord Med. 2008;31(4):379-87. https:// doi.org/10.1080/10790268.2008.11760740.

19. Spinal Cord Injury Thromboprophylaxis Investigators. Prevention of venous thromboembolism in the acute treatment phase after spinal cord injury: a randomized, multicenter trial comparing low-dose heparin plus intermittent pneumatic compression with enoxaparin. J Trauma. 2003;54(6):1116-24; discussion 1125-6. https://doi.org/10.1097/01.Ta.0000066385.10596.71.

20. Thumbikat P, Poonnoose PM, Balasubrahmaniam P, Ravichandran G, McClelland MR. A comparison of heparin/warfarin and enoxaparin thromboprophylaxis in spinal cord injury: the Sheffield experience. Spinal cord. Aug 2002:40(8):416-20. https://doi.org/10.1038/s.sc.3101325.

21. Higgins JPT, Thompson SG, Deeks JJ, Altman DG. Measuring inconsistency in meta-analyses. BMJ (Clinical research ed). 2003;327(7414):557-60. https:// doi.org/10.1136/bmj.327.7414.557.

22. Roberts TT, Leonard GR, Cepela DJ. Classifications in brief: American Spinal Injury Association (ASIA) Impairment Scale. Clin Orthop Relat Res. 2017; 475(5):1499-504. https://doi.org/10.1007/s11999-016-5133-4.

23. Liu Y, Xu H, Liu F, et al. Meta-analysis of heparin therapy for preventing venous thromboembolism in acute spinal cord injury. Int I Surg (London, England). 2017:43. https://doi.org/10.1016/j.ijsu.2017.05.066.

24. Dukes EM, Kirshblum S, Aimetti AA, Qin SS, Bornheimer RK, Oster G. Relationship of American Spinal Injury Association Impairment Scale grade to post-injury hospitalization and costs in thoracic spinal cord injury. Neurosurgery. 2018;83(3):445-51. https://doi.org/10.1093/neuros/nyx425.

25. Aarabi B, Olexa J, Chryssikos T, Galvagno SM, Hersh DS, Wessell A, et al. Extent of spinal cord decompression in motor complete (American Spinal Injury Association Impairment Scale Grades A and B) traumatic spinal cord injury patients: post-operative magnetic resonance imaging analysis of standard operative approaches. J Neurotrauma. 2019;36(6):862-76. https:// doi.org/10.1089/neu.2018.5834

26. Miano TA, Cuker A, Christie JD, Martin N, Smith B, Makley AT, et al. Comparative effectiveness of enoxaparin vs dalteparin for thromboprophylaxis after traumatic injury. Chest. Jan 2018;153(1):133-42. https://doi.org/10.1016/j.chest.2017.08.008.

27. Spiro TE, Johnson GJ, Christie MJ, Lyons RM, MacFarlane D, Blasier RB, et al. Efficacy and safety of enoxaparin to prevent deep venous thrombosis after hip replacement surgery. Enoxaparin Clinical Trial Group. Ann Intern Med. 1994;121(2):81-9. https://doi.org/10.7326/0003-4819-121-2-199407150-00001.

\section{Publisher's Note}

Springer Nature remains neutral with regard to jurisdictional claims in published maps and institutional affiliations.

Ready to submit your research? Choose BMC and benefit from:

- fast, convenient online submission

- thorough peer review by experienced researchers in your field

- rapid publication on acceptance

- support for research data, including large and complex data types

- gold Open Access which fosters wider collaboration and increased citations

- maximum visibility for your research: over $100 \mathrm{M}$ website views per year

At $\mathrm{BMC}$, research is always in progress.

Learn more biomedcentral.com/submissions 